Alexander D. Cornet

Nicole P. Juffermans

\section{There is no place (yet) for routine administration of sildenafil to patients with ARDS}

Accepted: 3 March 2010

Published online: 24 March 2010

(C) The Author(s) 2010. This article is published with open access at Springerlink.com

This reply refers to the comment available at: doi:10.1007/s00134-010-1865-x.

Dear editor: We thank Namendys and colleagues for their comments and would like to respond here. We do not concur with their statement that sildenafil should not be administered to patients with ARDS and would like to elucidate our point of view. We are under the impression that Namendys and coworkers feel that the results may have been different if only patients meeting the current definition of pulmonary artery hypertension had been included [1]. We need to emphasize that the study we recently reported on in this journal [2] was performed in patients meeting the NAECC criteria for ARDS [3], but not necessarily meeting the criteria of pulmonary arterial hypertension (PAH) [1]. In only five out of the ten patients, MPAP was $>25 \mathrm{mmHg}$, PAOP was $\leq 15 \mathrm{mmHg}$, and PVR was $>3$ Wood units (240 dyne $\times$ s/cm5).

Our hypothesis was that by selectively reducing the pulmonary vascular tone in ARDS by means of sildenafil, the shunt fraction would decrease, and oxygenation would thereby improve. This hypothesis, however, was only in part supported by our results: pulmonary vascular tone decreased; oxygenation and shunt fraction did not improve.
An important cause for these findings may have been sepsis. NO-mediated systemic (and pulmonary) vasodilation may have been enhanced by sildenafil as an intrinsic consequence of its mode of action. Due to the pronounced drop in systemic blood pressure, preferential vasodilation was not reached, explaining the deterioration in oxygenation and shunt fraction. Sepsis, or other inflammatory conditions requiring vasopressive support, frequently coincide with ARDS, thereby potentially rendering the treatment of pulmonary hypertension more complicated in patients suffering from ARDS as compared to ambulatory patients. However, in a recent study assessing the hemodynamic and gas exchange effects of sildenafil in patients with chronic obstructive pulmonary disease and pulmonary hypertension, the effects of sildenafil were much alike [4]. Sildenafil improved pulmonary hemodynamics at rest and during exercise, but also decreased systemic arterial blood pressure and led to a deterioration of arterial oxygenation, which was ascribed to inhibition of hypoxic pulmonary vasoconstriction. The improvement in exercise capacity of sildenafil in ambulatory patients with PAH may be primarily the consequence of hemodynamic and not of ventilatory effects [5]. In ARDS, it remains to be questioned whether therapy should be targeted on oxygenation, since levels of $\mathrm{PaO}_{2}$ have not been associated with adverse outcome in ARDS. The beneficial effect of sildenafil on right ventricular performance may be of additional value besides other strategies (e.g., ventilation in prone position) in patients with severe PAH who do not have arterial hypotension.

Namendys and colleagues further suggest that the approved dosage of sildenafil in PAH is $20 \mathrm{mg}$ three times daily, and the $50 \mathrm{mg}$ administered as a single dose in our study may have been too much. Yet, in ambulatory patients with COPD and $\mathrm{PAH}$, there was no significant difference in hemodynamic effects between a 20- and 40-mg dose [4].

Finally, we emphasize our study was designed as a "proof of concept study" and to obtain physiologic information. It was underpowered to make a statement on the effect of sildenafil on the outcome in patients suffering from ARDS. Therefore, until a large, sufficiently powered and well-designed trial determines this effect, sildenafil should be considered potentially useful in selected patients with stable hemodynamics and lifethreatening ARDS.

Open Access This article is distributed under the terms of the Creative Commons Attribution Noncommercial License which permits any noncommercial use, distribution, and reproduction in any medium, provided the original author(s) and source are credited.

\section{References}

1. McLaughlin VV, Archer SL, Badesch DB, Barst RJ, Farber HW, Lindner JR, Mathier MA, McGoon MD, Park MH, Rosenson RS, Rubin LJ, Tapson VF, Varga J, Harrington RA, Anderson JL, Bates ER, Bridges CR, Eisenberg MJ, Ferrari VA, Grines CL, Hlatky MA, Jacobs AK, Kaul S, Lichtenberg RC, Lindner JR, Moliterno DJ, Mukherjee D, Pohost GM, Rosenson RS, Schofield RS, Shubrooks SJ, Stein JH, Tracy CM, Weitz HH, Wesley DJ (2009) ACCF/ AHA 2009 expert consensus document on pulmonary hypertension: a report of the American College of Cardiology Foundation Task Force on Expert Consensus Documents and the American Heart Association: developed in collaboration with the American College of Chest Physicians, American Thoracic Society, and the Pulmonary

Hypertension Association. Circulation 119:2250-2294

2. Cornet AD, Hofstra JJ, Swart EL, Girbes AR, Juffermans NP (2010) Sildenafil attenuates pulmonary arterial pressure but does not improve oxygenation during ARDS. Intensive Care Med. doi:10.1007/s00134-010-1754-3 
3. Bernard GR, Artigas A, Brigham KL, Carlet J, Falke K, Hudson L, Lamy M, Legall JR, Morris A, Spragg R (1994)

The American-European Consensus Conference on ARDS. Definitions, mechanisms, relevant outcomes, and clinical trial coordination.

Am J Respir Crit Care Med 149:818-824

4. Blanco I, Gimeno E, Munoz PA, Pizarro S, Gistau C, Rodriquez-Roisin R, Roca J, Barbera JA (2010) Hemodynamic and gas exchange effects of sildenafil in patients with chronic obstructive pulmonary disease and pulmonary hypertension. Am J Respir Crit Care Med 181:270-278
5. Galiè N, Ghofrani HA, Torbicki A, Barst RJ, Rubin LJ, Badesch D, Fleming T, Parpia T, Burgess G, Branzi A, Grimminger F, Kurzyna M, Simonneau G (2005) Sildenafil citrate therapy for pulmonary arterial hypertension. N Engl J Med 353:2148-2157

A. D. Cornet (-

Department of Intensive Care Medicine, VU University Medical Center,

7D112, De Boelelaan 1117, $1081 \mathrm{HV}$

Amsterdam, The Netherlands

e-mail: cornet@vumc.nl

Tel.: +31-20-4443933

Fax: +31-20-4442392
N. P. Juffermans

Department of Intensive Care Medicine, Academic Medical Center,

Amsterdam, The Netherlands 